\title{
DNA OF FREE-LIVING BODONIDS \\ (EUGLENOZOA: KINETOPLASTEA) IN BAT ECTOPARASITES: POTENTIAL RELEVANCE TO THE EVOLUTION OF PARASITIC TRYPANOSOMATIDS
}

Krisztina SzÖKE ${ }^{1}$, Attila D. SÁNDOR ${ }^{2}$, Sándor A. BOLDOGH ${ }^{3}$, Tamás GÖRFÖL ${ }^{4}$, Jan VotÝPKA ${ }^{5,6}$, Nóra TAKÁCs ${ }^{1}$, Péter Estók ${ }^{7}$, Dávid KovÁTs ${ }^{8}$, Alexandra CORDUNEANU $^{2}$, Viktor MOLNÁR ${ }^{9}$, Jenő KONTSCHÁN ${ }^{10}$ and Sándor HORNOK ${ }^{1 *}$

${ }^{1}$ Department of Parasitology and Zoology, University of Veterinary Medicine, István u. 2, H-1078 Budapest, Hungary; ${ }^{2}$ Department of Parasitology and Parasitic Diseases, University of Agricultural Sciences and Veterinary Medicine, Cluj-Napoca, Romania; ${ }^{3}$ Department of Nature Conservation, Aggtelek National Park Directorate, Jósvafö, Hungary; ${ }^{4}$ Department of Zoology, Hungarian Natural History Museum, Budapest, Hungary; ${ }^{5}$ Department of Parasitology, Faculty of Science, Charles University, Prague, Czech Republic; ${ }^{6}$ Institute of Parasitology, Biology Centre, Ceske Budejovice, Czech Republic; ${ }^{7}$ Department of Zoology, Eszterházy Károly University, Eger, Hungary;

${ }^{8}$ Department of Evolutionary Zoology and Human Biology, Debrecen University, Debrecen, Hungary; ${ }^{9}$ Hannover Adventure Zoo, Hannover, Germany; ${ }^{10}$ Plant Protection Institute, Centre for Agricultural Research, Hungarian Academy of Sciences, Budapest, Hungary

(Received 1 August 2017; accepted 6 November 2017)

Kinetoplastids are flagellated protozoa, including principally free-living bodonids and exclusively parasitic trypanosomatids. In the most species-rich genus, Trypanosoma, more than thirty species were found to infect bats worldwide. Bat trypanosomes are also known to have played a significant role in the evolution of $T$. cruzi, a species with high veterinary medical significance. Although preliminary data attested the occurrence of bat trypanosomes in Hungary, these were never sought for with molecular methods. Therefore, amplification of an approx. 900-bp fragment of the 18S rRNA gene of kinetoplastids was attempted from 307 ixodid and 299 argasid ticks collected from bats, and from 207 cimicid bugs collected from or near bats in Hungary and Romania. Three samples, one per each bat ectoparasite group, were PCR positive. Sequencing revealed the presence of DNA from free-living bodonids (Bodo saltans and neobodonids), but no trypanosomes were detected. The most likely source of bodonid DNA detected here in engorged bat ectoparasites is the blood of their bat hosts. However, how bodonids were acquired by bats, can only be speculated. Bats are known to drink from

*Corresponding author; E-mail: Hornok.Sandor@univet.hu; Phone: 0036 (1) 478-4187

This is an open-access article distributed under the terms of the Creative Commons Attribution License, which permits unrestricted use, distribution, and reproduction in any medium for non-commercial purposes, provided the original author and source are credited. 
freshwater bodies, i.e. the natural habitats of $B$. saltans and related species, allowing bats to ingest bodonids. Consequently, these results suggest that at least the DNA of bodonids might pass through the alimentary mucosa of bats into their circulation. The above findings highlight the importance of studying bats and other mammals for the occurrence of bodonids in their blood and excreta, with potential relevance to the evolution of free-living kinetoplastids towards parasitism.

Key words: Bodo saltans, Neobodo, Trypanosoma, Chiroptera, evolution

Kinetoplastids are a class of flagellated protozoa (Euglenozoa: Kinetoplastea), named after a DNA-containing structure, the kinetoplast, which is part of their mitochondrion. They could be divided into two main groups, the trypanosomatids and the bodonids, with free-living and parasitic species (Lukeš et al., 2014). Trypanosomatids include several genera of monoxenous insect parasites (Maslov et al., 2013), and three dixenous genera comprise hundreds of species many of which are devastating parasites of animals and/or humans (e.g. Trypanosoma cruzi or Leishmania donovani, the causative agent of Chagas disease and KalaAzar, respectively). Bodonids contain ubiquitous free-living species (e.g. Bodo saltans) in freshwater, soil and marine habitats, as well as ecto- and endoparasites of fish, amphibians and molluscs (e.g., Ichthyobodo, Trypanoplasma, Perkinsela and Cryptobia). A common ground to consider the interrelatedness of these two kinetoplastid categories lies in their evolutionary history, because obligate parasitic trypanosomatids most likely developed from free-living $B$. saltans (Simpson et al., 2006; Flegontov et al., 2013; Lukeš et al., 2014).

More than 30 Trypanosoma spp. are known to infect bats (da Costa et al., 2016). The significance of bats in the evolution of (human) parasitic trypanosomatids attracted great attention in the past years, because T. cruzi and related species of various mammalian orders were shown to evolve from bat trypanosomes, as a result of host switching (Hamilton et al., 2012). This is not only substantiated by modern phylogenetic studies, but had also been suggested $a$ priori on a morphological basis (Molyneux and Bafort, 1971).

In Hungary, bat trypanosomes were found in a former, unpublished case (Fig. 1), but have never been sought for with molecular methods. During the past years research on bat ectoparasites broadened in this region of Central Europe (Hornok et al., 2014, 2016, 2017). Bats are highly protected mammals in Hungary and in Romania; consequently, research on pathogens associated with bats focused on non-invasive sampling methods, e.g., ectoparasites and faeces (Hornok et al., 2012, 2015a). Therefore, it was decided to screen a large sample collection of blood-sucking bat ectoparasites (ixodid and argasid ticks, as well as cimicid bugs) for DNA of kinetoplastids. In this context, cimicid bat bugs were the most relevant to test, as they are competent vectors of bat trypanosomes (Gardner and Molyneux, 1988). 

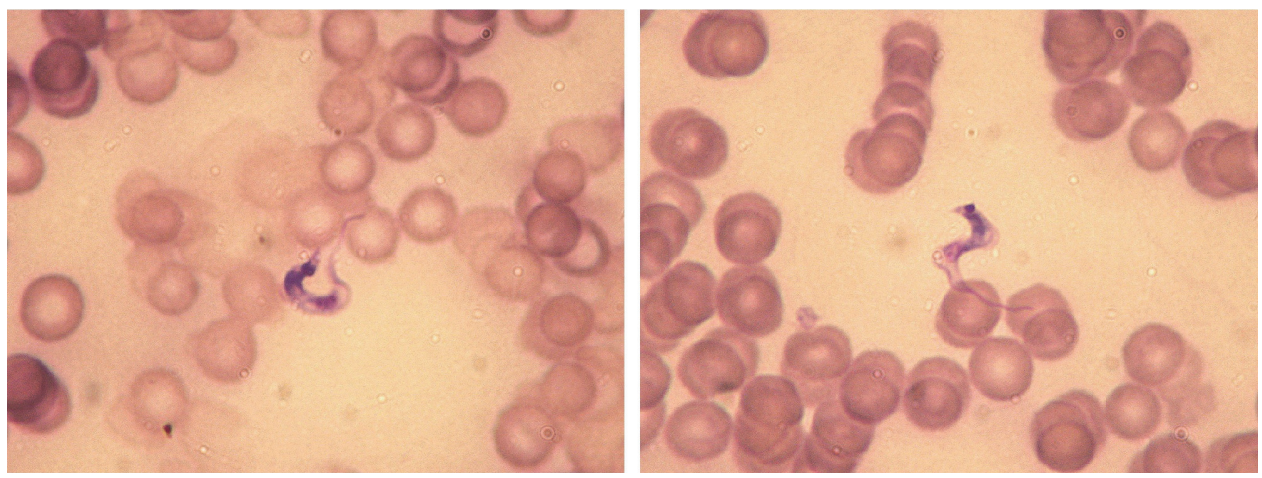

Fig. 1. Trypanosoma sp. in the blood smear of Nyctalus noctula (sampled by Viktor Molnár). This bat was randomly chosen and identified as trypanosoma-infected in a colony, which was rescued during a building reconstruction in the autumn of 1994 in Budakalász, Hungary.

Because this was an individual case, it is mentioned here only in support of the occurrence of bat trypanosomes in Hungary

\section{Materials and methods}

\section{Sample collection}

Ectoparasites (engorged ixodid and argasid ticks from bats, cimicid bugs from bats or near their colonies) were collected in Hungary and Romania between 2008 and 2015. Three species of ixodid ticks (Ixodes ariadnae, I. vespertilionis, and I. simplex) were collected on 24 locations in Hungary and seven locations in Romania (Hornok et al., 2016), Argas vespertilionis on 12 locations in Hungary and two locations in Romania (Hornok et al., 2017), and two Cimex species (C. pipistrelli and C. lectularius) on six locations in Hungary and two locations in Romania (data not shown). Out of 307 ixodid ticks, 45 I. ariadnae specimens have been collected from nine bat species (three genera), 124 I. vespertilionis specimens from 12 bat species (five genera), and 138 I. simplex specimens from Miniopterus schreibersii. Argas vespertilionis was represented by 299 larvae collected from 15 bat species (six genera), and cimicid bugs by 207 specimens from four bat species (two genera) (Table 1).

The bats were caught for monitoring and ringing purposes at cave entrances from sunset to dawn, using harp traps or Ecotone mist-nets (Gdynia, Poland) of standard size (12 m length, $2.5 \mathrm{~m}$ height and $14 \times 14 \mathrm{~mm}$ mesh size). Bats were released immediately after parasite removal; their species and sex were recorded. The ectoparasites were immediately put into and stored in $70-95 \%$ ethanol. Morphological identification was carried out with a stereomicroscope (SMZ-2T, Nikon Instruments, Japan) using standard morphological keys (for more detail see Hornok et al., 2015b, 2017). 
Table 1

Bat ectoparasites used in this study

\begin{tabular}{|c|c|c|c|c|c|c|}
\hline \multicolumn{2}{|c|}{ Hosts } & \multicolumn{5}{|c|}{ Number of samples (total) } \\
\hline Family & $\begin{array}{c}\text { Genus } \\
\text { (number } \\
\text { of species) }\end{array}$ & $\begin{array}{c}\text { Argas } \\
\text { vespertilionis } \\
(299)\end{array}$ & $\begin{array}{l}\text { Ixodes } \\
\text { ariadnae } \\
(45)^{*}\end{array}$ & $\begin{array}{c}\text { Ixodes } \\
\text { vespertilionis } \\
(124)\end{array}$ & $\begin{array}{l}\text { Ixodes } \\
\text { simplex } \\
(138)\end{array}$ & $\begin{array}{l}\text { Cimex } \\
\text { spp. } \\
(207)\end{array}$ \\
\hline \multirow[t]{6}{*}{ Vespertilionidae } & Pipistrellus (4) & 161 & - & - & - & 1 \\
\hline & Myotis (10) & 58 & 33 & 60 & - & 206 \\
\hline & Nyctalus (1) & 4 & - & - & - & - \\
\hline & Eptesicus (1) & 16 & - & 3 & - & - \\
\hline & Plecotus (2) & 28 & 4 & 1 & - & - \\
\hline & Vespertilio (1) & 32 & - & - & - & - \\
\hline Rhinolophidae & Rhinolophus (4) & - & 1 & 58 & - & - \\
\hline Miniopteridae & Miniopterus (1) & - & - & 2 & 138 & - \\
\hline
\end{tabular}

*including seven engorged specimens from cave walls

\section{DNA extraction and molecular analyses}

DNA was extracted as described (Hornok et al., 2016), including surface decontamination of each arthropod with sequential washing in detergentcontaining water, then in tap water, and finally in sterile (autoclaved) distilled water. Ethanol (in which the ectoparasites were stored), detergents and sterile distilled water are known to remove surface DNA contamination (Halos et al., 2004; Champlot et al., 2010). All arthropods were minced in $100 \mu 1$ sterile (autoclaved) PBS. DNA extraction was performed individually from ixodid ticks, individually or in pools of two to three larvae from A. vespertilionis, and individually from cimicid bugs with the QIAamp DNA Mini Kit (QIAGEN, Hilden, Germany) according to the manufacturer's instructions, including extraction controls in each procedure. Between each sample the scissors were washed and burned to avoid cross-contamination. Samples were incubated overnight in tissue lysis buffer with proteinase- $\mathrm{K}$ at $56^{\circ} \mathrm{C}$.

DNA samples were molecularly screened with a conventional PCR that amplifies an approx. 900-bp-long fragment of the 18S (SSU) rRNA gene of trypanosomes and related kinetoplastids. The primers 609F (forward: 5'-CAC CCG CGG TAA TTC CAG C-3') (da Silva et al., 2004) and 706R (reverse: 5'-CTG AGA CTG TAA CCT CAA-3') (Ramírez et al., 2012) were used in a reaction volume of $25 \mu \mathrm{l}$, which included $5 \mu \mathrm{l}$ of extracted DNA, and $20 \mu \mathrm{l}$ of reaction mixture containing 0.5 unit HotStarTaq Plus DNA polymerase (5U/ $\mu \mathrm{l}), 200 \mu \mathrm{M}$ PCR nucleotide mix, $1 \mu \mathrm{M}$ each primer and $2.5 \mu \mathrm{l}$ of $10 \times$ Coral Load PCR buffer (15 mM MgCl 2 included). For amplification, an initial denaturation step at $95{ }^{\circ} \mathrm{C}$ 
for $5 \mathrm{~min}$ was followed by 40 cycles of denaturation at $94{ }^{\circ} \mathrm{C}$ for $40 \mathrm{~s}$, annealing at $49{ }^{\circ} \mathrm{C}$ for $1.5 \mathrm{~min}$ and extension at $72{ }^{\circ} \mathrm{C}$ for $1 \mathrm{~min}$. Final extension was performed at $72{ }^{\circ} \mathrm{C}$ for $5 \mathrm{~min}$. All PCRs were run with positive control (sequenceverified T. avium) and negative control (non-template reaction mixture). During the tests, positive controls showed positivity, whereas negative (non-template) controls and extraction controls remained negative (the latter indicating the absence of sample contamination). PCR products were electrophoresed and visualised in a $1.5 \%$ agarose gel. Purification and sequencing of PCR products were done by Biomi Inc. (Gödöllö, Hungary). The obtained sequences were submitted to GenBank (accession numbers MF000702-4).

\section{Ethical approval}

Authorisation for bat capture was provided by the National Inspectorate for Environment and Nature in Hungary (No. 14/2138-7/2011) and the Underground Heritage Commission in Romania. Bat banding license numbers are TMF-14/32/2010 (DK), 59/2003 (PE) and TMF-493/3/2005 (TG), TMF-513/1/ 2004 (SAB).

\section{Results}

Three DNA samples of bat ectoparasites were PCR positive for kinetoplastids. In these samples sequencing revealed the presence of DNA from freeliving bodonids, but none from trypanosomes. In particular, one I. simplex larva (collected from Mi. schreibersii captured in Somova, Romania) contained the DNA of $B$. saltans, with $99.7 \%(754 / 756 \mathrm{bp})$ identity to a reference sequence (AY490224). In addition, the DNA of Bodonidae was detected in one A. vespertilionis larva (collected from Myotis brandtii captured at Mánfa cave, Mecsek Mountains, Hungary) and in one C. pipistrelli nymph (collected near the $M y$. blythii/myotis colony in a church at Szőlösardó, Hungary). Corresponding sequences were $100 \%$ (i.e. 776/776 bp) identical with Bodonidae sp. Pan-2 (AY753625).

Phylogenetic analysis of these three DNA-positive samples (Fig. 2) showed that the sequence of $B$. saltans from the bat tick I. simplex aligned closest to other $B$. saltans isolates within the Eubodonida clade, which is a sister group to the Neobodonida clade that includes the two bodonid sequences amplified from the bat tick $A$. vespertilionis and the bat bug $C$. pipistrelli. 


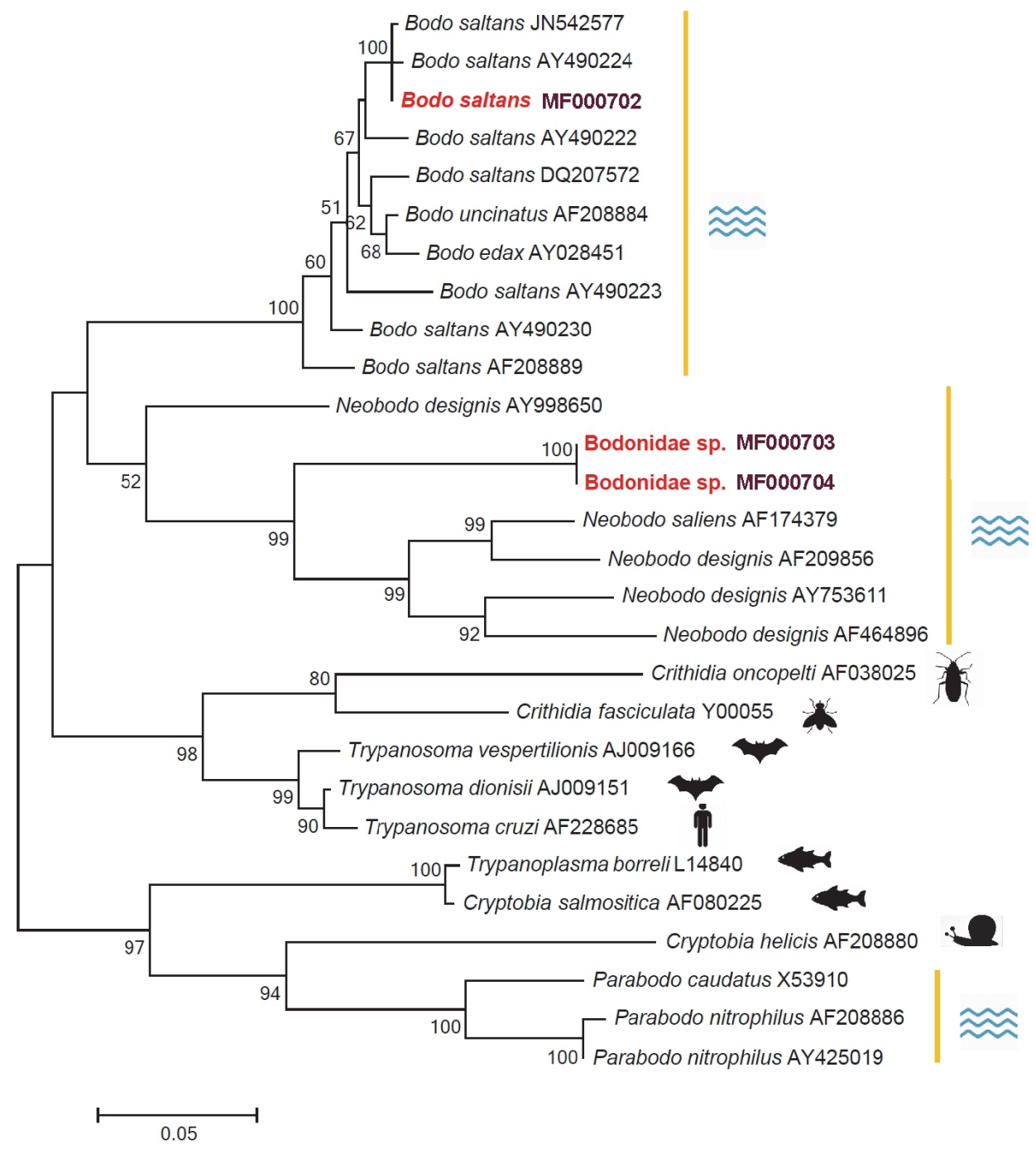

Fig. 2. Maximum Likelihood phylogenetic tree of an approx. 900-bp-long fragment of the $18 \mathrm{~S}$ rRNA gene, including sequences obtained in this study (highlighted by red fonts and bold accession numbers) and representative sequences of other kinetoplastids retrieved from GenBank. The pictographic symbols indicate the typical hosts or water in case of free-living bodonid species. Branch lengths represent the number of substitutions per site inferred according to the scale shown

\section{Discussion}

Morphological and molecular-phylogenetic evidences strongly support the origin of parasitic trypanosomatids from free-living bodonids like $B$. saltans (Simpson et al., 2006; Flegontov et al., 2013; Lukeš et al., 2014). In this study, 
three DNA extracts from bat ectoparasites were shown to be PCR-positive for kinetoplastids, and in these samples sequencing identified free-living (waterassociated) bodonids. The arthropod-origin of these bodonids is confirmed by the PCR negativity of extraction controls throughout the study. Furthermore, because prior to DNA extraction the surface of investigated arthropods was decontaminated, the DNA of identified bodonids must have been present within these ectoparasites.

The typical natural habitat of $B$. saltans and related bodonids is freshwater (Mitchell et al., 1988). Taking into account that neither ixodid/argasid bat ticks nor cimicid bat bugs develop in water, and these ectoparasites live in a very close association with their terrestrial bat hosts, it is reasonable to suppose that these arthropods could not ingest bodonids from an aquatic environment. In addition, both PCR-positive ticks were larvae, i.e. did not feed in a previous stage, but were collected during their first blood meal. Therefore, in the absence of known transovarial transmission of Bodonidae in ticks, the most likely source of bodonid DNA detected here in obligatorily haematophagous bat ectoparasites is the blood of their bat hosts. If so, this phenomenon is not completely new, because free-living species of bodonids were reported to occur in the urine and faeces of various mammals other than bats (Das Gupta and Chatterjee, 1938; Vandersea et al., 2015). In addition, bodonid DNA was repeatedly detected in blood samples obtained from ungulates (Auty et al., 2012; Jan Votýpka, unpublished data).

Results of the present study are in line with the finding of $B$. saltans-like DNA in the blood of bats in South America (Dario et al., 2017). Although in the relevant study (Dario et al., 2017) the authors could not entirely rule out that detection of $B$. saltans-like DNA in bat blood samples resulted from environmental contamination during sampling, their precautions argued against this. In the present study environmental contamination related to the sampling procedure can be excluded, because bat ectoparasites were put into ethanol on the premises, and it is very unlikely that $B$. saltans (or its DNA) would withstand ethanol-based disinfection (Dario et al., 2017). In addition, bat ectoparasites of the present study were further surface-disinfected under laboratory conditions, and not only the DNA of $B$. saltans was detected in them (for which the possibility of contamination during sampling was considered on account of its ubiquity: Dario et al., 2017), but also the DNA of a neobodonid.

Unfortunately, even when assuming that bodonid DNA amplified in the present study derived from the blood of bats, it can only be speculated how these protists were acquired by bats. Although echolocating bats are predominantly insectivorous, and may thus have access to a wide range of insect-parasitic monoxenous trypanosomatids (e.g. Crithidia spp.) in their insect food, these are an unlikely source of bodonids identified in the present study, because Bodonidae includes only a few entomophilic species (Lipa, 1963), and in particular B. saltans is not known to occur in insects. 
On the other hand, all bat species rely on drinking from freshwater bodies (Greif and Siemers, 2010). Such occasions may allow bats to ingest bodonids, although this has not been suggested formerly on a molecular basis.

Animal and human feeding studies have demonstrated that fragmented dietary DNA may resist the digestive process (Rizzi et al., 2012) and even complete genes can transgress the gut barrier (Spisák et al., 2013). Taking into account this scenario, the present findings might imply that bats have access to free-living bodonids and at least the DNA of bodonids might pass through the oropharyngeal or gastrointestinal mucosa of bats into their circulation. Similarly, this was the most likely mechanism explaining the presence of DNA from piroplasms of ruminants and dogs in bat ticks (Hornok et al., 2016).

It might be relevant to note in this context that bats are susceptible to $T$. cruzi (which, according to phylogenetic evidence, evolved from bat trypanosomes), and bats may acquire T. cruzi infection orally (Klimpel and Mehlhorn, 2013). This necessitates the ability of $T$. cruzi to pass through the oral/gastric mucosa (Thomas et al., 2007), similarly to other stercorarian trypanosomes (Lima et al., 2013). However, to the best of the authors' knowledge, this has not been demonstrated in case of bodonids.

At the same time, it was unexpected that none of the bat ectoparasites were found to contain the DNA of bat-specific trypanosomes. The quantity and quality of the DNA in the tick extracts, molecularly analysed here for kinetoplastids, were verified in other studies involving the same samples (Hornok et al., 2016, 2017); therefore, based on their PCR negativity, these ticks did not contain trypanosomes. One plausible explanation is that none of the bats sampled in this study were infected with Trypanosoma spp., i.e. their ectoparasites were also trypanosome free. On the other hand, it is also possible that some of the tickinfested bats were infected with trypanosomes, but these bats had low parasitaemias and the few trypanosomes in the tick blood meal became digested after phagocytosis by midgut cells. This latter phenomenon might account for the PCR negativity of non-vector ticks, even when collected from hosts harbouring trypanosomes in their blood, as observed by others (Botero et al., 2016).

The above findings highlight the importance of studying bats and other mammals for the occurrence of bodonids in their blood and excreta. This phenomenon should be investigated further as a potential, hitherto missing link in the evolution of free-living kinetoplastids towards parasitism.

\section{Acknowledgements}

The study was organised in the frame of EurNegVec COST Action TD1303. The molecular part of the study was performed with financial support from OTKA K 115854. Sample collection in Romania was supported by the grant PN-II-RU-TE-2014-4-1389, and a grant from Domus Hungarica, Hungarian Academy of Sciences (to ADS). The 
publication of this research was supported by the 12190-4/2017/FEKUTSTRAT grant of the Hungarian Ministry of Human Capacities.

\section{References}

Auty, H., Anderson, N. E., Picozzi, K., Lembo, T., Mubanga, J., Hoare, R., Fyumagwa, R. D., Mable, B., Hamill, L., Cleaveland, S. and Welburn, S. C. (2012): Trypanosome diversity in wildlife species from the Serengeti and Luangwa Valley ecosystems. PLoS Negl. Trop. Dis. 6, e1828.

Botero, A., Cooper, C., Thompson, C. K., Clode, P. L., Rose, K. and Thompson, R. C. A. (2016): Morphological and phylogenetic description of Trypanosoma noyesi sp. nov.: an Australian wildlife trypanosome within the T. cruzi clade. Protist 167, 425-439.

Champlot, S., Berthelot, C., Pruvost, M., Bennett, E. A., Grange, T. and Geigl, E. M. (2010): An efficient multistrategy DNA decontamination procedure of PCR reagents for hypersensitive PCR applications. PLoS ONE 5, e13042.

da Costa, A. P., Nunes, P. H., Leite, B. H. S., Ferreira, J. I. G. da S., Tonhosolo, R., da Rosa A. R., da Rocha, P. A., Aires, C. C., Gennari, S. M. and Marcili, A. (2016): Diversity of bats trypanosomes in hydroelectric area of Belo Monte in Brazilian Amazonia. Acta Trop. 164, $185-193$.

da Silva, F. M., Noyes, H., Campaner, M., Junqueira, A. C. V., Coura, J. R., Añez, N., Shaw, J. J., Stevens, J. R. and Teixeira, M. M. G. (2004): Phylogeny, taxonomy and grouping of Trypanosoma rangeli isolates from man, triatomines and sylvatic mammals from widespread geographical origin based on SSU and ITS ribosomal sequences. Parasitol. 129, 549-561.

Dario, M. A., Moratelli, R., Schwabl, P., Jansen, A. M. and Llewellyn, M. S. (2017): Small subunit ribosomal metabarcoding reveals extraordinary trypanosomatid diversity in Brazilian bats. PLoS Negl. Trop. Dis. 11, e0005790.

Das Gupta, B. M. and Chatterjee, H. (1938): Observations on a Bodo-like flagellate persistently occurring in the faeces of a human being. Parasitol. 30, 56-60.

Flegontov, P., Votýpka, J., Skalický, T., Logacheva, M. D., Penin, A. A., Tanifuji, G., Onodera, N. T., Kondrashov, A. S., Volf, P., Archibald, J. M. and Lukeš, J. (2013): Paratrypanosoma is a novel early-branching Trypanosomatid. Curr. Biol. 23, 1787-1793.

Gardner, R. A. and Molyneux, D. H. (1988): Trypanosoma (Megatrypanum) incertum from Pipistrellus pipistrellus: development and transmission by cimicid bugs. Parasitol. 96, 433-447.

Greif, S. and Siemers, B. M. (2010): Innate recognition of water bodies in echolocating bats. Nat. Commun. 1, 107.

Halos, L., Jamal, T., Vial, L., Maillard, R., Suau, A., Le Menach, A., Boulouis, H. J. and VayssierTaussat, M. (2004): Determination of an efficient and reliable method for DNA extraction from ticks. Vet. Res. 35, 709-713.

Hamilton, P. B., Teixeira, M. M. G. and Stevens, J. R. (2012): The evolution of Trypanosoma cruzi: the 'bat seeding' hypothesis. Trends Parasitol. 28, 136-141.

Hornok, S., Estók, P., Kováts, D., Flaisz, B., Takács, N., Szőke, K., Krawczyk, A., Kontschán, J., Gyuranecz, M., Fedák, A., Farkas, R., Haarsma, A-J. and Sprong, H. (2015a): Screening of bat faeces for arthropod-borne apicomplexan protozoa: Babesia canis and Besnoitia besnoiti-like sequences from Chiroptera. Parasit. Vectors 8, 441.

Hornok, S., Kontschán, J., Estrada-Peña, A., de Mera, I. G. F., Tomanović, S. and de la Fuente, J. (2015b): Contributions to the morphology and phylogeny of the newly discovered bat tick species, Ixodes ariadnae in comparison with I. vespertilionis and I. simplex. Parasit. Vectors. 8, 47 . 
Hornok, S., Kontschán, J., Kováts, D., Kovács, R., Angyal, D., Görföl, T., Polacsek, Z., Kalmár, Z. and Mihalca, A. D. (2014): Bat ticks revisited: Ixodes ariadnae sp. nov. and allopatric genotypes of I. vespertilionis in caves of Hungary. Parasit. Vectors 7, 202.

Hornok, S., Kovács, R., Meli, M. L., Kontschán, J., Gönczi, E., Gyuranecz, M., Dán, Á., Molnár, V. and Hofmann-Lehmann, R. (2012): First detection of bartonellae in a broad range of bat ectoparasites. Vet. Microbiol. 159, 541-543.

Hornok, S., Szőke, K., Kováts, D., Estók, P., Görföl, T., Boldogh, S. A., Takács, N., Kontschán, J., Földvári, G., Barti, L., Corduneanu, A. and Sándor, A. D. (2016): DNA of piroplasms of ruminants and dogs in ixodid bat ticks. PLoS ONE 11, e0167735.

Hornok, S., Szőke, K., Tu, V. T., Kontschán, J., Takács, N., Sándor, A. D., Halajian, A., Földvári, G., Estók, P., Plantard, O., Epis, S. and Görföl, T. (2017): Mitochondrial gene heterogeneity of the bat soft tick Argas vespertilionis (Ixodida: Argasidae) in the Palaearctic. Parasit. Vectors 10, 109.

Klimpel, S. and Mehlhorn, H. (eds) (2013): Bats (Chiroptera) as Vectors of Diseases and Parasites: Facts and Myths. First edition. Springer, Berlin, Heidelberg. 187 pp.

Lima, L., Espinosa-Álvarez, O., Hamilton, P. B., Neves, L., Takata, C. S. A., Campaner, M., Attias, M., de Souza, W., Camargo, E. P. and Teixeira, M. M. (2013): Trypanosoma livingstonei: a new species from African bats supports the bat seeding hypothesis for the Trypanosoma cruzi clade. Parasit. Vectors 6, 221.

Lipa, J. J. (1963): Infection caused by Protozoa other than Sporozoa. In: Steinhaus, A. E. (ed.) Insect Pathology. An Advanced Treatise. Second edition. Academic Press, New York. pp. 335-358.

Lukeš, J., Skalický, T., Týč, J, Votýpka, J. and Yurchenko, V. (2014): Evolution of parasitism in kinetoplastid flagellates. Mol. Biochem. Parasitol. 195, 115-122.

Maslov, D. A., Votýpka, J., Yurchenko, V. and Lukes, J. (2013): Diversity and phylogeny of insect trypanosomatids: all that is hidden shall be revealed. Trends. Parasitol. 29, 43-52.

Mitchell, G. C., Baker, J. H. and Sleigh, M. A. (1988): Feeding of a freshwater flagellate, Bodo saltans, on diverse bacteria. J. Protozool. 35, 219-222.

Molyneux, D. H. and Baffort, J. M. (1971): Observations on the trypanosome of Pipistrellus pipistrellus in Britain, Trypanosoma (Schizotrypanum) vespertilionis. Ann. Soc. Belg. Med. Trop. 51, 335-348.

Ramírez, J. D., Duque, M. C., Montilla, M., Cucunubá, Z. M. and Guhl, F. (2012): Natural and emergent Trypanosoma cruzi I genotypes revealed by mitochondrial (Cytb) and nuclear (SSU rDNA) genetic markers. Exp. Parasitol. 132, 487-494.

Rizzi, A., Raddadi, N., Sorlini, C., Nordgrd, L., Nielsen, K. M. and Daffonchio, D. (2012): The stability and degradation of dietary DNA in the gastrointestinal tract of mammals: implications for horizontal gene transfer and the biosafety of GMOs. Crit. Rev. Food. Sci. Nutr. 52, $142-161$.

Simpson, A. G. B., Stevens, J. R. and Lukeš, J. (2006): The evolution and diversity of kinetoplastid flagellates. Trends Parasitol. 22, 168-174.

Spisák, S., Solymosi, N., Ittzés, P., Bodor, A., Kondor, D., Vattay, G., Barták, B. K., Sipos, F., Galamb, O., Tulassay, Z., Szállási, Z., Rasmussen, S., Sicheritz-Ponten, T., Brunak, S., Molnár, B. and Csabai, I. (2013): Complete genes may pass from food to human blood. PLoS ONE 8, e69805.

Thomas, M. E., Rasweiler, IV J. J. and D'Alessandro, A. (2007): Experimental transmission of the parasitic flagellates Trypanosoma cruzi and Trypanosoma rangeli between triatomine bugs or mice and captive neotropical bats. Mem. Inst. Oswaldo Cruz 102, 559-565.

Vandersea, M. W., Birkenheuer, A. J., Litaker, R. W., Vaden, S. L., Renschler, J. S. and Gookin, J. L. (2015): Identification of Parabodo caudatus (class Kinetoplastea) in urine voided from a dog with hematuria. J. Vet. Diagn. Invest. 27, 117-120. 